\title{
携帯型超音波診断装置によるロ腔癌頸部リンパ節転移の診断精度
}

\author{
外丸雅晴 ${ }^{1)} \cdot$ 林 孝文 ${ }^{2)} \cdot$ 新垣 晋 ${ }^{1)} \cdot$ 齊藤 力 $^{1)}$
}

\section{Diagnostic accuracy of a portable ultrasound system for the detection of cervical lymph node metastases in patients with oral cancer}

\author{
TOMARU Masaharu ${ }^{1)} \cdot$ HAYASHI Takafumi ${ }^{2)}$ \\ SHINGAKI Susumu ${ }^{1)} \cdot$ SAITO Chikara ${ }^{1)}$
}

\begin{abstract}
Purpose: To assess the clinical significance of a portable ultrasound system for the diagnosis of lymph node metastasis in patients with oral cancer, we investigated the diagnostic accuracy of sonography as compared with histopathological results.

Materials and methods: From January 2007 through July 2008, 26 consecutive patients with oral cancer who underwent neck dissection were studied. A total of 268 sonographically detected lymph nodes were histopathologically evaluated for metastasis, and a side-by-side comparison of lymph nodes between preoperative sonography and histopathology was performed. The portable ultrasound equipment we used was a GE LOGIQ-e with a 5-13 $\mathrm{MHz}$ linear transducer. On sonography, a metastatic lymph node was defined as a lymph node with a minimal axial diameter of more than $8 \mathrm{~mm}$ that lacked an echogenic hilum, had a heterogeneous internal structure that reflected central necrosis, or both.

Results: Of the 268 nodes, 45 nodes were metastatic, and the remaining 223 were non-metastatic on histopathological examination. When the lymph nodes were compared between preoperative sonography and histopathological specimens on a side-by-side basis, the sensitivity, specificity, and accuracy for the detection of metastasis were $64.4 \%, 98.7 \%$, and $92.9 \%$, respectively.

Conclusion: Although the sensitivity was slightly low, our results suggested that the portable ultrasound system was useful for the detection of cervical lymph node metastasis in patients with oral cancer, particularly during postoperative follow-up.
\end{abstract}

Key words: oral cancer (口腔癌), lymph node metastasis（頸部リンパ節転移）， ultrasonography（超音波診断）， portable ultrasound system（携帯型超音波診断装置）

緒言

口腔癌治療において，頸部リンパ節転移の制御は，治療

1) 新潟大学大学院医茵学総合研究科顎顔面再建学講座組織 再建口腔外科学分野 (主任 : 齊藤 力教授)

2) 新潟大学大学院医茵学総合研究科顎顔面再建学講座顎顔 面放射線学分野

(主任：林 孝文教授)

${ }^{1)}$ Division of Reconstructive Surgery for Oral and Maxillofacial Region, Department of Tissue Regeneration and Reconstruction, Niigata University Graduate School of Medical and Dental Sciences (Chief: Prof. SAITO Chikara)

${ }^{2)}$ Division of Oral and Maxillofacial Radiology, Department of Tissue Regeneration and Reconstruction, Niigata University Graduate School of Medical and Dental Sciences (Chief: Prof. HAYASHI Takafumi)

受付日：2008 年 12 月 15 日

採択日：2009年 5 月 26 日
成績に大きな影響を与える要素の一つである. そして, 頸 部リンパ節転移の個数や領域, 周囲への進展状態などを正 確に診断することは, 口腔癌治療において極めて重要であ る. 現在, 頸部リンパ節転移の診断に際しては, 触診は無 論のこと, 超音波診断 (US), X 線コンピュータ断層撮影 (CT), 磁気共鳴影像法 (MRI) および Positron Emission Tomography（PET）など, 各種画像診断法が利用されて いる.しかしながら，いずれの診断法にも長所と短所があ り, 複数の画像診断法を組み合わせて利用しているのが現 状である ${ }^{1)}$.

超音波診断法は，放射線被曝を伴わず，装置も CT や MRI に比べて小型で安価であり, リアルタイムで画像の観 察が可能である長所を有しており, 口腔顎顔面領域におい ても触診の延長として繰り返し検査を行うことが可能で ある ${ }^{2)}$. 近年の超音波診断装置の進歩に伴い, アーチファ 
表1 対象症例の性別と年齢

\begin{tabular}{ccc}
\hline & 対象数 (例) & 年齢 $($ 平均士標準偏差 $)$ \\
\hline 男性 & 17 & $59 \pm 11.9$ \\
女性 & 9 & $72.9 \pm 6.0$ \\
全体 & 26 & $63.8 \pm 12.1$ \\
\hline
\end{tabular}

クトの少ない鮮明な画像が得られ, 微細な血行動態の把握 も可能になってきており ${ }^{3)}$, 特に携帯型はより小型化の傾 向にあり，わずかなスペースでも使用可能なことから，往 診や巡回診療, 災害時などの救急対応にも利用されてきて いる ${ }^{3,4)}$. 画質においても，腹部領域などでは，据え置き型 と同等で, 初期診断に打いて全く問題のない画像が得られ るとの報告 ${ }^{3)}$ もある. 今回我々は, 㐘科のチェアサイドで も使用が容易な携帯型超音波診断装置を用いて, 口腔癌転 移リンパ節の診断精度についてリンパ節単位で検討したの で，その概要について報告する。

\section{対象 - 方法}

2007 年 1 月から 2008 年 7 月までの間に, 新潟大学医㐘 学総合病院・㐘科にて頸部郭清術を施行した口腔領域の扁 平上皮癌（SCC）患者のうち, 術前にUS 検查を施行した 26 例を対象とした. 内訳は, 男性 17 名・女性 9 名であり, 平均年齢は男性 59.0 歳, 女性 72.9 歳, 全体では 63.8 歳で あった（表 1). 原発巣の $\mathrm{T}$ 分類は, $\mathrm{T} 1$ 症例 10 例・ $\mathrm{T} 2$ 症 例 10 例・ $\mathrm{T} 4$ 症例 6 例であった. 原発部位別では, 舌が 14 例と最も多く, ついで下顎菊肉が 6 例, 口底 3 例, 上顎柬 肉 2 例, 煩粘膜 1 例の順であった. 左右両側の頸部郭清術 が行われたのは 2 例であった. 後発転移を生じたために頸 部郭清術を施行したのは 11 例であった（表 2). 原発巣の 病理組織学的診断は全例扁平上皮癌であった。

携帯型 US 装置には，ノートパソコン型の GE 社製 LOGIQe（幅 $340 \mathrm{~mm} \times$ 奥行き $287 \mathrm{~mm}$ ×高さ $61 \mathrm{~mm}$ ・重 量約 $4.6 \mathrm{~kg}$ ）と $5 \sim 13 \mathrm{MHz}$ 電子リニア探触子（12L-RS） を用いた. 撮像に際しては, 音響カップリング材としてエ コーゼリーを用い, 頸部皮膚表面に探触子を密着させて走 査した. US 画像上, 明瞭にリンパ節として再現性をもって 認識しえたリンパ節について, その横断像と縦断像を記録 した.

転移陽性判定基準は，グレースケール画像上，リンパ門 が不明瞭で短径が $8 \mathrm{~mm}$ を越えた場合, あるいは大きさに 関係なくリンパ節内部に中心壊死領域が認められた場合と した.リンパ門については, US 画像上, リンパ節周囲の脂 肪組織と連続性を有する, 辺縁の鮮明な高エコーの陥凹と
表2 原発部位とT分類の内訳

\begin{tabular}{|c|c|c|c|c|c|c|}
\hline \multirow{2}{*}{ T分類 } & \multicolumn{6}{|c|}{ 原発部位（例） } \\
\hline & 舌 & 煩粘膜 & 上顎歯肉 & 下顎歯肉 & 口底 & 合計 \\
\hline $\mathrm{T} 1$ & $6(4)$ & 1 & 0 & $1(1)$ & 2 & 10 \\
\hline $\mathrm{T} 2$ & $7(3)$ & 0 & 0 & $2(1)$ & $1(1)$ & 10 \\
\hline T3 & 0 & 0 & 0 & 0 & 0 & 0 \\
\hline $\mathrm{T} 4$ & 1 & 0 & 2 & $3(1)$ & 0 & 6 \\
\hline 合計 & 14 & 1 & 2 & 6 & 3 & 26 \\
\hline
\end{tabular}

定義した. 転移の有無の判定は, 超音波診断経験 3 年以上 の柬科放射線科医 4 名が行い, 判断に迷った場合や意見が 異なった場合は合議し, リンパ節に持続的な増大や中心壞 死領域の拡大など経時的変化が明らかに認められた場合に 転移と判断した。超音波ドプラ法によるリンパ節の血流情 報は, グレースケール画像での所見確認の参考としたが, 本装置のドプラでの判定基準が未確定なため, 単独での転 移の判定根拠とはしなかった。頸部郭清術前の US 像と頸 部郭清術により摘出されたリンパ節を照合して, 術前 US の診断精度を検証した。術前 US と頸部郭清術までの期間 は，最短 2 日・最長 64 日，平均 22.8 日であった。

\section{結果}

本稿における診断精度の定義については, 以下のとおり とする. 真陽性 (true-positive; TP）とは, 画像で転移と診 断し実際に病理組織学的に転移が認められたものであり, 真陰性（true-negative; TN）とは, 画像で非転移と診断し 実際に病理組織学的に転移が認められなかったもの, 偽陽 性（false-positive; FP） とは, 画像で転移と診断し実際には 病理組織学的に転移が認められなかったもの，偽陰性 (false-negative; FN) とは画像で非転移と診断し実際には 病理組織学的に転移が認められたものを意味する。感度 sensitivity は, TP/(TP + FN) で定義され, 実際に病理組 織学的に転移が認められたもののうち, 画像で転移と正し く診断できていたものの割合を示す. 特異度 specificity は, $\mathrm{TN} /(\mathrm{TN}+\mathrm{FP})$ で定義され, 実際に病理組織学的に転移 が認められなかったもののうち, 画像で非転移と正しく診 断できていたものの割合を示す. 正診率 accuracy は, $(\mathrm{TP}+\mathrm{TN}) /(\mathrm{TP}+\mathrm{TN}+\mathrm{FP}+\mathrm{FN})$ で定義され，す心゙て の対象のうちで正しく診断できていたものの割合を示す.

頸部郭清術により摘出され, 病理組織学的にリンパ節と して判断されたものは，778個であった．転移腫瘍により 全体が置換され本来のリンパ節構造を失っていた場合も, 
表3 1症例あたりの転移リンパ節数の分布

\begin{tabular}{cc}
\hline 転移リンパ節数 $($ 個 $)$ & 症例数 $($ 例 $)$ \\
\hline 1 & 12 \\
2 & 5 \\
3 & 2 \\
4 & 1 \\
5 & 0 \\
6 & 1 \\
7 & 1 \\
\hline
\end{tabular}

表4 部位別の転移リンパ節の個数

\begin{tabular}{cc}
\hline 部 位 & 転移リンパ節数 $($ 個 $)$ \\
\hline 顎下リンパ節 & 20 \\
上内頸静脈リンパ節 & 13 \\
中内頸静脈リンパ節 & 9 \\
舌リンパ節 & 2 \\
下内頸静脈リンパ節 & 1 \\
\hline
\end{tabular}

臨床経過から転移リンパ節と判断しこれに含めた。それら の病理組織学的検索の結果, 症例単位では転移陽性が 22 例, 転移陰性が 4 例であった. 転移陽性症例 22 例における 病理組織学的転移陽性リンパ節の個数は 45 個であった. 1 症例あたりの転移リンパ節の個数は, 最多で 7 個 (1 例), 最少で 1 個（12 例）であった（表 3)．部位別では，顎下リ ンパ節が 20 個と最も多く, 上内頸静脈リンパ節 13 個, 中 内頸静脈リンパ節 9 個の順で多く認められた. 残りの転移 陽性リンパ節は舌リンパ節が 2 個で，下内頸静脈リンパ節 が 1 個であった（表 4).

頸部郭清術前 US で郭清領域内に検出されていたリンパ 節の総数は 268 個であった（両側の頸部郭清術が行われた 2 例では両側を対象とした).これは摘出リンパ節 778 個の $34.4 \%$ 相当した. US 画像上，前述した診断基準により転 移陽性と判定したリンパ節は 32 個であり, 転移陰性と判 定したリンパ節は 236 個であった.

病理組織学的検索の結果, 摘出リンパ節 778 個の内訳は, 転移陽性 45 個, 転移陰性 733 個であった. リンパ節摘出分 類を図示した手術記事におけるリンパ節の大きさ, 肉眼的 所見, 存在位置を参考に, 術前 US で検出された 268 個に ついて摘出リンパ節との一対一照合を行った。 その結果, US で転移陽性と判定した 32 個のリンパ節はすべて病理標 本と照合できた。このうち 29 個は病理組織学的に転移陽 性（真陽性）であり，3 個は転移陰性（偽陽性）であった. US で転移陰性と判定した 236 個については, 病理組織学
表5 真陽性・真陰性・偽陽性・偽陰性のリンパ節数

\begin{tabular}{cr}
\hline & リンパ節数 (個) \\
\hline 真陽性true-positive & 29 \\
真陰性true-negative & 220 \\
偽陽性false-positive & 3 \\
偽陰性false-negative & 16 \\
\hline 計 & 268
\end{tabular}

表6 診断精度

\begin{tabular}{ll}
\hline 感度sensitivity & $64.4 \%$ \\
特異度specificity & $98.7 \%$ \\
正診率accuracy & $92.9 \%$ \\
\hline
\end{tabular}

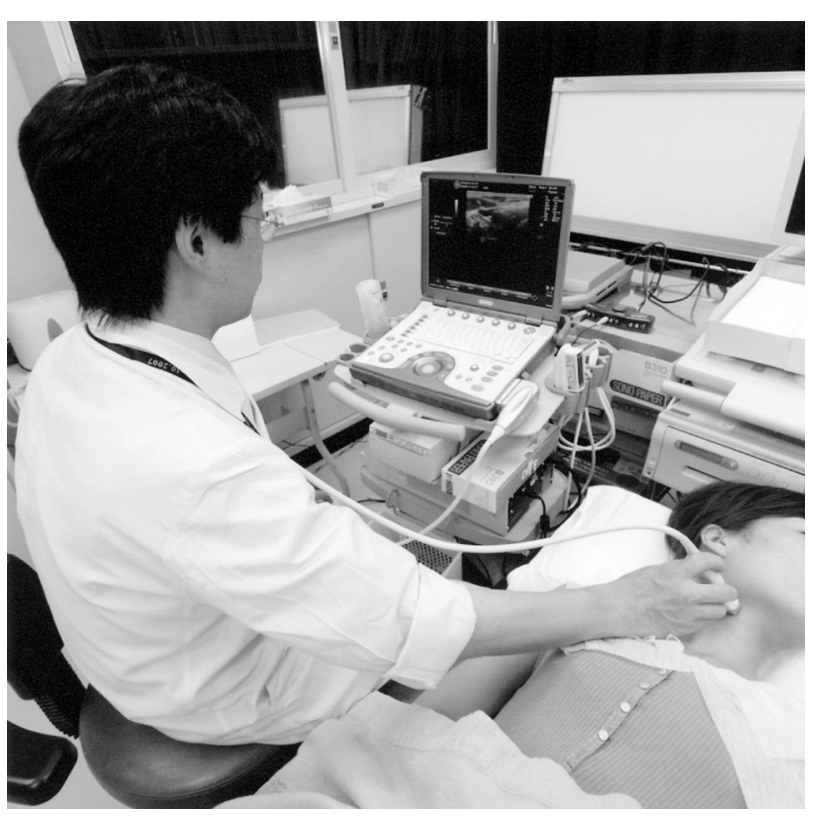

写真 1 携帯型超音波診断装置による検査の様子

的に転移陽性であった 16 個は一対一照合が可能であった (偽陰性) ため, 残りの病理組織学的転移陰性リンパ節 220 個は照合困難であったものの, 真陰性と解釈しうると判断 した（表 5).

以上より, リンパ節単位での診断精度は, 感度 $64.4 \%$, 特異度 $98.7 \%$, 正診率 $92.9 \%$ であった（表 6 ）。真陽性の リンパ節の例を写真 2 に, 偽陰性のリンパ節の例を写真 3 に，偽陽性のリンパ節の例を写真 4 に示す. 

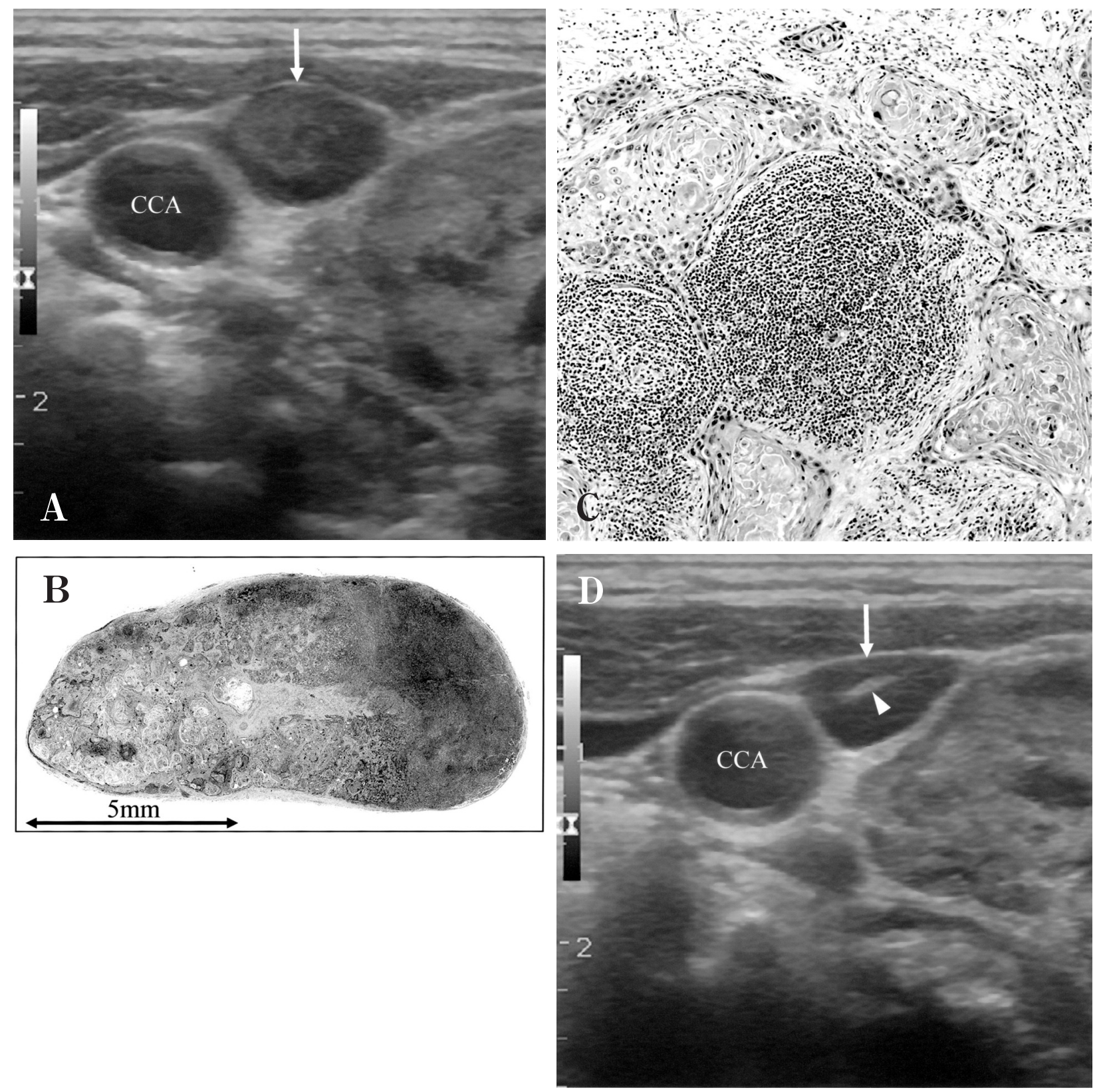

写真 2 真陽性リンパ節（84 歳・女性，右側舌扁平上皮癌）

A : 頸部郭清術前 US 横断像. 右側中内頸静脈リンパ節（矢印）の短径は $7 \mathrm{~mm}$ と比較的小さいが，リンパ門を有さ ず，内部に辺縁不鮮明な高エコー域が認められる. 初診時より 159 日後の時点で転移陽性と判定した. CCA：総 頸動脈.

B：摘出リンパ節の病理組織マクロ像 (H-E 染色). リンパ節の大半を占める転移腫痬巣が認められる.

C：同リンパ節の転移腫瘍巣の病理組織像 (H-E 染色, X 100).

D : 初診時の US 横断像. 右側中内頸静脈リンパ節 (矢印) の短径は $4 \mathrm{~mm}$ で, 明瞭なリンパ門を有し (矢頭), 内部 は均一な低エコーである.この時点では転移陽性とは診断できない. 写真 A と比較すると, 経時的に短径が増大 しリンパ門が消失し, 内部エコーが不均一となる変化が確認できる. CCA：総頸動脈.

考

察

口腔癌頸部リンパ節転移の超音波診断において，携帯型 装置という点に論点を置いた報告はほとんど認められな
$い^{5)}$. 超音波検査の長所は，低コストで検査が簡便であり， 被曝を伴わず非侵襲的であるため, 繰り返しの検査が容易 に行える点である. 近年では, 据え置き型に匹敵する性能 を有する携帯型超音波診断装置も普及しつつある ${ }^{3} \sim 5$ ) 

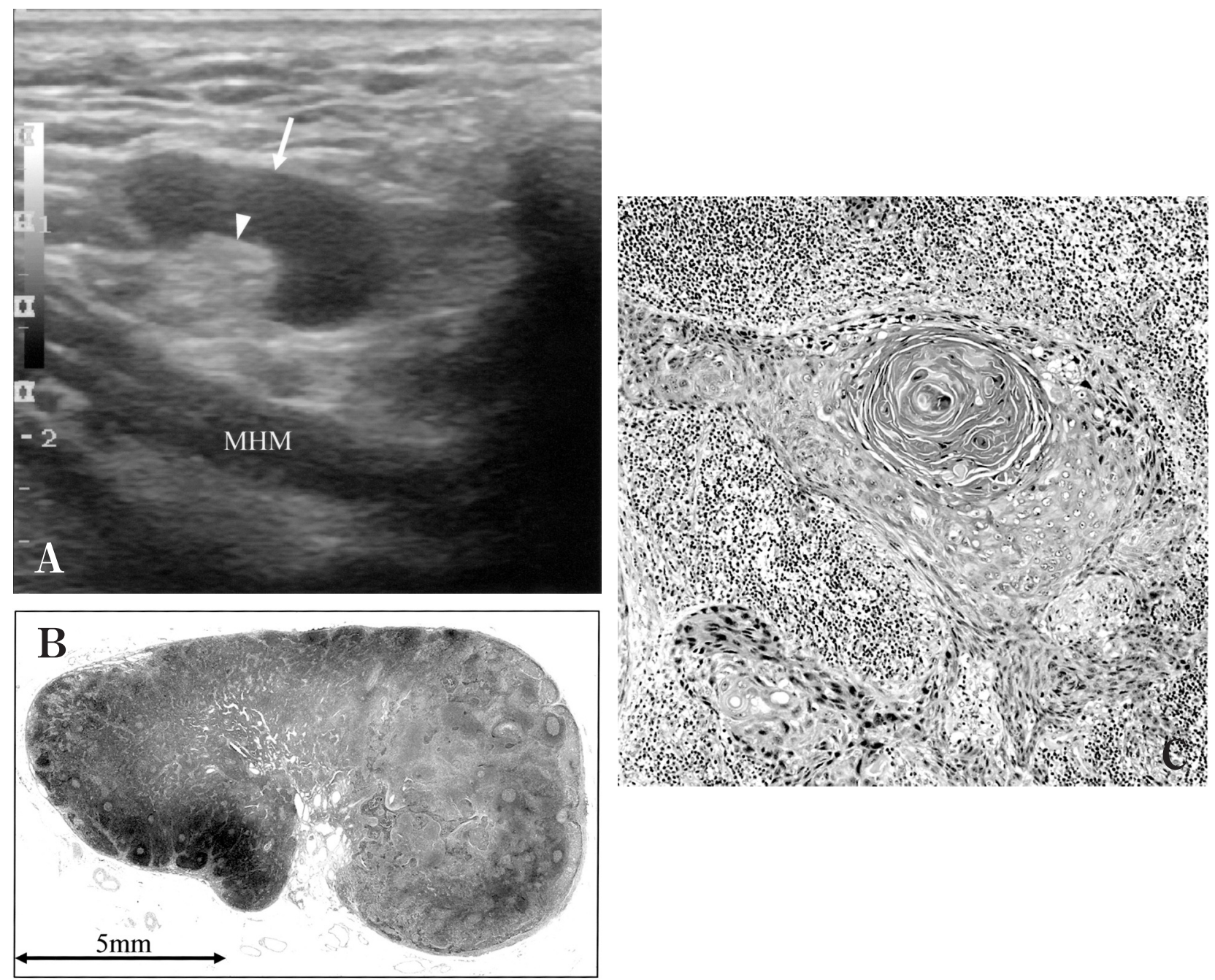

写真 3 偽陰性リンパ節（56 歳・男性，左側舌扁平上皮癌）

A：頸部郭清術前 US 縦断像. 左側顎下リンパ節（矢印）の短径は $7 \mathrm{~mm}$ と比較的小さく, 明瞭なリンパ門 (矢頭) を有し, 内部エコーは均一な低エコーで中心壊死を疑わせる所見は認められない. 形状もリンパ節本来の楕円形 が保たれて扣り，転移陰性と判定した. MHM：䫟舌骨筋.

B：摘出リンパ節の病理組織マクロ像 (H-E 染色)。リンパ節の半分程度を占める転移腫瘍巣が認められる.

C ：同リンパ節の転移腫瘍巣の病理組織像 (H-E 染色, X 100).

特に医科領域においては, 救急医療や病棟ベッドサイドで の診察や往診，巡回医療への応用が期待されている ${ }^{4)}$. 口 腔癌頸部リンパ節転移の画像診断法としては, US 以外に は CT P MRI, PET な゙が用いられているが，いずれの検 查法も専用の施設が必要となり, 検查に要する費用が US と比較し高価であることや, 放射線被曝の問題などから, 繰り返しの検査が困難である欠点を有している. 口腔癌の 原発巣治療後 1 年半程度までの間は, 頸部後発リンパ節転 移の早期発見のために, 1 か月に 1 回程度の US 検査の施 行が推奨 $\left.{ }^{1}\right)$ されており, スペースを選ばず, ベッドサイド やチェアサイドでの検査が容易な携帯型超音波診断装置 は，繰り返し検査することが容易であるというUSの長所
をさらに伸ばすことが期待される. 特に, 㐘科診療におけ るチェアサイドの頸部リンパ節転移の診査法として, 触診 に携帯型装置による US 検査が加わることで, 口腔癌頸部 リンパ節転移の検出精度はより向上し, 治療成績の向上に つながると考えられる。

口腔癌の頸部リンパ節転移の診断精度に関しては, CT, MRI, USのいずれの検査法においても感度, 特異度, 正診 率にかなりの幅があることが報告されている ${ }^{1,6,7)}$.いず れの検査法においても, それぞれの撮影条件や診断基準が 一律でなく, 大きさの診断基準も長径や短径が混在してい るためのこうした差が生じると推測 ${ }^{1)}$ されており, 単純に 相互比較をすることは困難である.ただし, 一般的にUS 

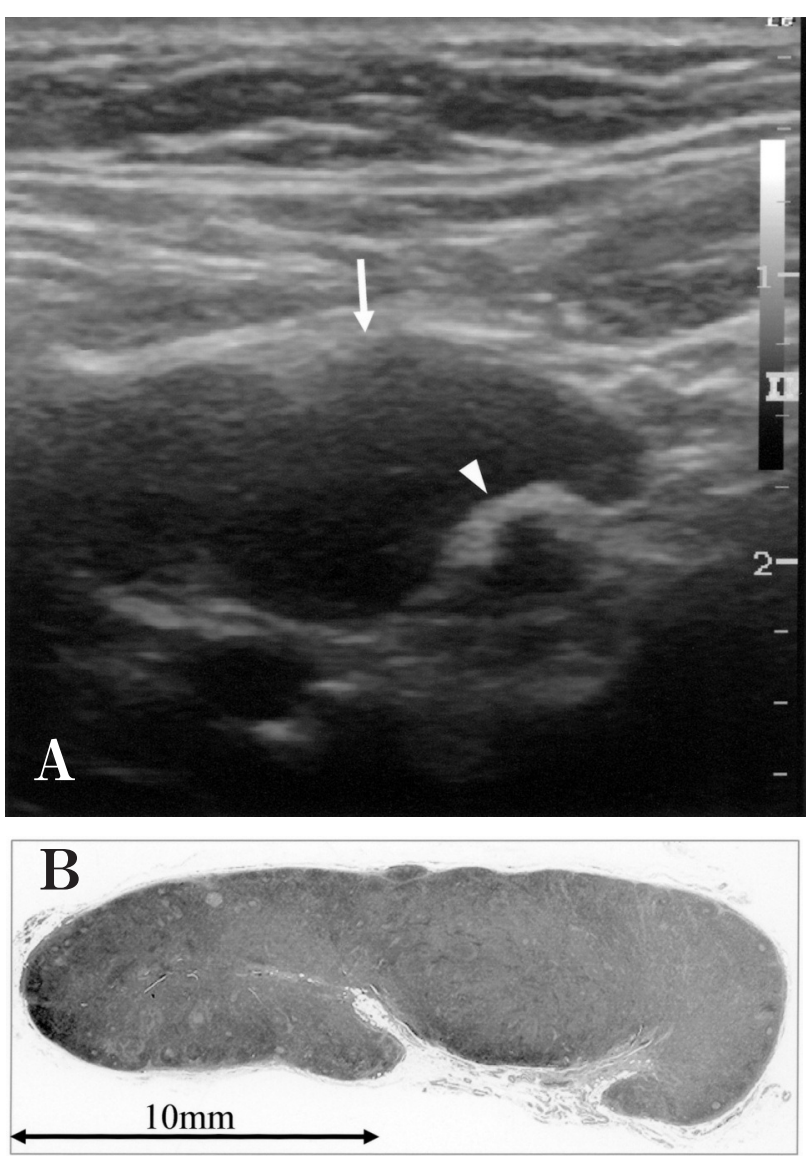

写真 4 偽陽性リンパ節（61歳・男性, 左側舌扁平上皮 癌)

A : 頸部郭清術前 US 横断像. 左側上内頸静脈リンパ節 (矢印) は, リンパ門 (矢頭) は浅く平坦で, 短径は $10 \mathrm{~mm}$ と腫大像であり，転移陽性と判定した。

B：摘出リンパ節の病理組織マクロ像 (HE 染色).リン パ節内に転移腫瘍巣は認められない。

では特異度と比較し感度が低くなる傾向が認められている 1,8).これは, 圧倒的多数を占める非転移リンパ節に対し限 定された数の転移リンパ節という状況による数值の偏りに 起因するものであり, 特異度は限りなく $100 \% に$ に近くなる 性格があり, 本研究のような検索方法を用いる限り, この ような傾向になることは当然と考えられる。

一般的に転移リンパ節の画像所見として呈示されている のは, リンパ節の大きさと, 転移腫瘍の中心壊死などによ り生じたリンパ節内部の欠損像である ${ }^{1,8)}$. 欠損像が肉眼 レベルでリンパ節の構造上の変化として明瞭であれば, US でも内部エコーの変化としてとらえることが可能であり, 転移陽性と容易に診断可能である.しかしながら本研究で は, 過去の当施設の報告 ${ }^{8)}$ と比べて, 特異度と正診率は上 回っていたものの, 感度が低い結果となった。過去の報告
では，据え置き型の超音波診断装置を用い，本研究と同様 の診断基準により転移の有無を判定し, 感度が $86 \%$, 特異 度が $96 \%$ ，正診率が $93 \%$ あった．同一症例を対象とし ていないためその理由は明確ではないが, 今回対象とした 症例において, US 診断が偽陰性であったリンパ節 16 個の うち約半数に当たる 9 個が, $2 \mathrm{~mm}$ 以下の微小転移巣であ ったことが一因となったと思われる. 現在用いられている 画像診断法のいずれに打いても, 本質的に分解能の限界が あるために，こうしたリンパ節内部の微小転移巣を検出す るのは困難とされており ${ }^{9 \sim 11)}$, 装置の精度向上でも追い つかないこのような一定の限界は止むを得ないものと考え られる. 加えて, 本研究に打ける病理組織学的検索は連続 切片によるものではないため, 微小転移巣は実際にはより 多く存在していた可能性もあり, その場合感度はさらに低 いことになる.

一方，偽陰性リンパ節のなかには，微小転移巣ではなく リンパ節の半分程度から大部分を腫瘍組織が占めていて も，USで転移陽性と診断できなかった場合も存在した。こ れは, 腫瘍によっては壊死や角化による顕著な密度差を伴 わない場合があり, そのような状況では画像上検出困難と なるためである。このような状況に対応するために，リン パ節の短径や長短比が診断基準として呈示されており ${ }^{1)}$, 特に, リンパ節の短径や形態の経時的変化を詳細に追跡す ることにより, より早期に転移陽性と判断することが可能 と考えられている ${ }^{1,9)}$. 携帯型超音波診断装置がチェアサ イドに普及すれば，こうした経時的変化の詳細な観察も容 易になると思われる. 他方, このようなグレースケール画 像のみでは診断困難な症例に対しては, 超音波ドプラ法に よるリンパ節内の血流走行の異常の有無や, 超音波組織弾 性イメージング（エラストグラフィー）を用いた硬さの情報 などの付加的な情報も有用性が高いと考えられている ${ }^{1)}$. ドプラ検査では, リンパ節内の転移巣による周囲血管の圧 排所見が䛦断基準として呈示されている. 転移巣の増大と ともに，周囲の血管は圧排され，転移巣を取り囲むように 血管が走行すると考えられている ${ }^{12)}$. しかし, 血流の検出 精度は機種や撮影条件による影響が大きい. このため本研 究では, グレースケール画像を主体として評価し, ドプラ 所見はグレースケール所見を確認するための付加的な情報 として参照した. 今後は症例を重ねて, 今回使用した装置 に適したドプラ所見の診断基準を設定したいと考えてい る. また超音波組織弾性イメージングを積極的に導入する ことにより, 肉眼レベルの転移腫瘍巣の検出精度をあげて, 本研究において不十分な結果であった感度向上を四りたい と考える.

今回の研究から, 従来の報告と比較して感度がやや低い 傾向が認められたものの, 高い正診率が得られ, 携帯型装 
置による口腔癌頸部リンパ節転移の診断精度はスクリーニ ングには十分とはいえないまでも, 経時的変化を追跡する ことにより本領を発揮しうる可能性が推測された. 低コス トで検査が簡便であり, 被曝を伴わず非侵襲的であるため 繰り返し検查することが容易な携帯型超音波診断装置は, 場所を選ばない使用が可能であり, 今後触診の補助として 歯科臨床に広く用いられるようになれば，口腔癌頸部リン パ節転移の早期発見につながり, 治療成績を向上させるの に有効と考えられる.

\section{結語}

歯科のチェアサイドでも利用が容易な携帯型超音波診断 装置を用いて, 口腔癌の頸部リンパ節転移の診断精度につ いて検討した。携帯型超音波診断装置は, 頸部リンパ節転 移診断において特に経過観察に有用性があると考えられ る.

\section{引用 文 献}

1）林 孝文, 新国 農, 他：口腔扁平上皮癌頸部リン パ節転移の画像診断. 新潟菌学会誌 37: 173-186 2007.

2) 有地榮一郎：口腔顎顔面領域に打ける超音波診断.
愛知学院大学歯学会誌 37: 375-383 1999 .

3）重田浩一朗，伊東紘一：携帯型超音波診断装置のも たらすもの一現状と今後の展望一. Medical Technology 30: 1038-1041 2002.

4）渡邊 望, 吉田 清: 携帯型超音波装置の活用。 ICU と CCU 27: 995-1002 2003.

5）有地淑子, 後藤真一, 他：ドプラ機能を有する携帯 用超音波診断装置（SonoSite）の頭頸部領域での使 用経験. 霜科放射線 43: 81-89 2003.

6) de Bondt, R.B., Nelemans, P.J., et al.: Detection of lymph node metastases in head and neck cancer: a meta-analysis comparing US, USgFNAC, CT and MR imaging. Eur J Radiol 64: 266-272 2007.

7）神田重信, 湯浅賢治, 他：口腔癌頸部リンパ節転移 に対する画像診断法のアプローチ. 㐘科放射線 40: 109-121 2000.

8）林 孝文, 伊藤寿介, 他： $10 \mathrm{MHz}$ 高分解能探触子 による口腔癌頸部リンパ節転移の US 診断. 口腔腫 瘍 6: 55-65 1994.

9）林 孝文：口腔癌頸部リンパ節転移の画像所見と病 理所見の対応について. 日口外誌 54: 361-367 2008.

10）中野敏昭，野口 誠，他：口腔扁平上皮癌の頸部リ ンパ節転移の超音波診断と偽陰性リンパ節の病理組 織学的特徴. 札幌医誌 72: 15-21 2003.

11）古川まどか, 久保田 彰, 他：頸部リンパ節転移の 超音波診断. 頭頸部腫瘍 27: 717-725 2001.

12）湯浅賢治，筑井 徹，他：超音波パワードプラ法を 用いたリンパ節内血流像による転移巣の䛦断. 頭頸 部腫瘍 27: 727-731 2001. 